\title{
Factors Affecting Job Satisfaction and Its Effect on Employee Resignation in the Mulia Health and Dental Care (MHDC) Clinic Group
}

\author{
Amanda Setiorini $^{1 *}$, Wiwik Rachmarwi ${ }^{2}$ \\ ${ }^{12}$ Universitas Krisnadwipayana, Jakarta 13077, Indonesia
}

\begin{abstract}
A B S T R A C T
This study wants to find out whether compensation, job safety, career paths, communication, relationships with superiors, and work-life balance affect job satisfaction, and how they affect employee resignation. From a population of 100 employees, a total of 73 people were sampled. The results show that compensation and work-life balance have a significant effect on job satisfaction and resignation, while relations with superiors have a significant effect on job satisfaction, and communication has a significant effect on resignation through job satisfaction.
\end{abstract}

ART I C LE I N F O

\author{
Article History: \\ Received : 09-07-2020 \\ Revised : 29-09-2020 \\ Accepted : 02-10-2020 \\ Published : 31-10-2020
}

Keywords:

Compensation

Job Safety

Career Path

Communication

Relationship with Superiors

Work-Life Balance

Job Satisfaction

Resignation

*Corresponding Author E-mail:

amanda.setiorini@unkris.ac.id

\section{INTRODUCTION}

Business organizations in any field need to pay more attention to the management of their employees. One of them is by paying attention to employee job satisfaction. Various studies that have been conducted on job satisfaction conclude that employee job satisfaction has a positive impact on business organizations (Setiorini, 2016). Robbins (2006, p. 32) states that employees who are satisfied with their work will be more productive, and this has been a basic principle in management for years. Conversely, employees who feel dissatisfied with their work will actually 
become a burden to the organization.

According to Robbins (2006, p. 105-107) job satisfaction has an impact on productivity, absence, resignation, and customer satisfaction. For employees who are the front liners and routinely deal with customers, their job satisfaction can increase customer satisfaction and loyalty. Because satisfied employees are more likely to display a friendly, cheerful, and responsive attitude-these things are valued by customers (Setiorini, 2016).

Other research also shows that job satisfaction is related to the emergence of prosocial behavior, which is behavior directed at supervisors, coworkers, and clients and has a positive impact on the company. Other studies have found a positive relationship between job dissatisfaction and higher counterproductive behavior in workers older than 30 years (Schultz \& Schultz, 2006, p. 241).

Mudor and Tooksoon (2011) propose that certain human resource management practices, namely supervision, job training, and payroll practices, create a favorable approach to job satisfaction. The direct impact of job satisfaction is a reduced desire to leave the company.

Wang, Yang, \& Wang (2012) research about job satisfaction and turnover in the public and private sector in Taiwan, show that public employees have lower extrinsic job satisfaction and lower turnover intentions compared to their counterparts in the private sector. The researchers state that to enhance employee motivation, public-sector managers should improve their employees' extrinsic job satisfaction and help unsatisfied employees transfer to jobs they find more satisfying.

One negative effect of low job satisfaction is employee turnover. Resignation causes various losses, one of which is because the company can lose potential employees, also due to the costs incurred in recruiting and training new employees. Losses can also be caused because new employees need time to adapt to the work environment.

Mulia Health and Dental Care (MHDC) is a group of clinics providing professional dental care services with dozens of experienced dentists and nurses. Until now, the MHDC clinic group has 12 branches in Jakarta and surrounding areas. As a services organization, MHDC needs to manage its employees in order to be able to provide services well. Managing employee job satisfaction is one of the management of human resources that needs attention.

By managing employee job satisfaction, MHDC can provide even better services to its customers. This certainly will bring positive consequences in business. In addition, by paying attention to job satisfaction, employees are expected to be happier to work at MHDC and reduce consideration for finding another job. This means managing MHDC employee job satisfaction will benefit both inside and outside MHDC as business organizations.

The problem is what factors do contribute to employee's job satisfaction in MHDC? This study uses the concept of Mello (2006, pp. 99-102) which states that job satisfaction is influenced by factors namely communication with management, work-life balance, relationships with superiors, career opportunities and paths, job safety, benefits, and compensation. We are focusing on these six factors and neglecting other factors that might have contributed to job satisfaction.

By using a questionnaire of 40 statements, we ask 100 employees-consisting of doctors, nurses, and staff, including administration, front office, and management, from all of the 12 branches. We received 75 responses, and 73 of them can be analyzed. According to Isaac and Michael tables, this number of samples taken has a significance level of $10 \%$. Influence analysis is carried out using a path diagram.

The result shows that only certain factors have contributed to job satisfaction and resignation. Compensation and work-life balance do have impact to job satisfaction and resignation, and 
communication has impact to resignation through job satisfaction.

\section{LITERATURE REVIEW}

Job satisfaction is defined as an individual's general attitude towards his job, which is reflected in the attitude of the individual (Robbins, 2006, pp. 31-32). Other definitions of job satisfaction are: expressions of employee satisfaction about how their work can benefit the organization, which means that what is gained in work fulfills what is considered important (Luthans in Almigo, 2004); positive emotional state as a result of evaluating one's work experience (Mathis \& Jackson, 2006, p. 547); and the positive and negative feelings and attitudes that employees feel about their work (Schultz \& Schultz, 2006, p. 232).

Job satisfaction arises as an affective or emotional response to various aspects of work. Work requires interaction with colleagues and superiors, including the ability to follow company rules and policies, meet certain performance standards, the ability to live in less than ideal work conditions, and others (Robbins \& Judge, 2013, p. 79). If someone does not get satisfaction in his work, it will encourage job stress. The aspects of work that can be a source of work stress include dimensions of organizational structure, job design, work groups, and individual characteristics (Robbins, Luthans in Setiorini, 2016).

This study uses the concept of Mello (2006, pp. 99-102) which states that job satisfaction is influenced by factors namely communication with management, work-life balance, relationships with superiors, career opportunities and paths, job safety, benefits, and compensation. From this concept, modifications were made to make the theme more general.

The "communication with management" factor is included in the "relationship with superiors" factor because communication is one way to form relationships, while communication becomes a separate factor that includes communication with everyone in the organization.
According to Robbins \& Judge (2013, p. 337), communication is a process of exchange and understanding of meaning. Communication provides information needed by individuals and groups to make decisions, by conveying the data needed to identify and evaluate available options.

Upholding polite and equal communication ethics is important so that even lower-level employees can express their thoughts and opinions. Repressing lines of communication at work can cause tension due to difficulty communicating work.

Communication flows from subordinates to superiors and vice versa, as well as communication with colleagues or colleagues who are equal. Communication from subordinates to the top often causes problems because of these different positions. There is still a culture where subordinates are reluctant to express different opinions-let alone arguing-with superiors.

Communication also becomes important in relationships with superiors. Communication with superiors is often a problem because the two parties are not in an equal position. This makes it difficult especially if superiors are concerned about their different positions so they do not open up opportunities for subordinates to convey their thoughts and opinions. However, lately there have been enough superiorssubordinate relationships that are more egalitarian.

According to (Dessler, 2017, p. 382), employee compensation is all forms of payment or gifts to employees arising from their work. Compensation can be in the form of direct or indirect. Direct financial payments are payments in the form of wage commissions and bonuses, while indirect ones take the form of financial benefits such as insurance. This concept underlying the merging of the "benefit" factor is also combined with "compensation" which means all benefits-both financial and non-financial-received by employees.

Compensation is an important factor because 
every worker is required to fulfill their daily needs. Referring to the motivational theory of Abraham Maslow, humans have a level of need that will drive their motivation. At the lower or first level are physiological needs, such as eating and drinking. To meet this need, people must work and get paid for their work.

At the highest level of need from Maslow's motivational theory, there is a need for selfactualization. This need is usually met not by compensation but by recognition. For example, someone is recognized for his work, like a painter.

The "career path and opportunity" factor is simplified to the "career path". Career (Dessler, 2017 , p. 345) is a job position held by someone for many years. Because careers are a part of human self-development in their work, every organization needs to do career management and planning.

Career management is a process for employees to better understand and develop their career skills and interests and use these skills and interests most effectively both within the company and after they leave the company (Dessler, 2017, p. 345). In career management, career development needs to occur, which is a series of lifelong activities that contribute to the exploration, development, success, and fulfillment of one's career (Dessler, 2017, p. 345).

Some jobs don't seem to have a clear career development path. Or, less communicating about career development so employees do not understand that they can develop themselves further. Some organizations may experience difficulties in making career planning and simply fill in the gaps that are needed. Things like this can happen to organizations that don't pay attention to human resource management.

Career planning is a deliberate process in which a person becomes aware of personal skills, interests, knowledge, motivation, and other characteristics; obtain information about opportunities and choices; identify career-related goals; and setting action plans to achieve certain goals (Dessler, 2017, p. 345).

Work-life balance is needed for several reasons (Robbins \& Judge, 2013, p. 21), namely: the creation of a global organization also means that the world never rests, communication technology allows people to work anywhere-which blurs the boundary between home and office (work), and a growing number of married couples working together makes the fulfillment of commitments to the family more challenging.

Numerous studies suggest that conflicts between life in the office and outside the office, specifically between work responsibilities with family, are a significant source of stress (Robbins \& Judge, 2013, p. 604). This becomes more difficult when there are small children, parents, sick people, and single parents in the family who need more attention.

Job safety is defined as the stability and security of a permanent (job) position (Mello, 2006, p. 101). According to Mello, the reason for this feeling of security is because most people believe in their own skills and abilities, the importance of their work for the success of the organization, and the importance of their years of service.

This sense of security is also important because having work guarantees one's ability to fulfill their daily needs. Thus, job security is also a guarantee of the fulfillment of one's life needs. But this trend may no longer be dominant in today's younger generation who tend to easily change jobs. They even feel comfortable with work that is temporary or based on the project. Finished one project, they will look for another project.

Resignation is the behavior of leaving an organization which includes finding a new position as well as resigning permanently voluntarily or forced from the organization. Resignation is usually the last step disclosed because the employee feels dissatisfied with his work. According to (Robbins, 2006, pp. 107-108), the response to job dissatisfaction can be seen 
from two dimensions: constructive/destructive and active/passive. Resignation is a response from the active and destructive dimensions.

\section{RESEARCH METHOD}

This study will examine whether factors such as compensation, job safety, career paths, communication, relationships with superiors, and work-life balance affect job satisfaction? Furthermore, will job satisfaction affect the resignation of MHDC employees?

The hypotheses tested in this study are as follows: whether there is an effect of compensation, job safety, career path, communication, relationship with superiors, and work-life balance on job satisfaction (1), whether there is an effect of compensation, job safety, career path, communication, relationships with superiors, work-life balance, and job satisfaction on resignation (2), and whether there is an effect of compensation, job safety, career path, communication, relationships with superiors, and work-life balance through job satisfaction on resignation (3).

The study was conducted by distributing questionnaires from Google Form through the WhatsApp application. This questionnaire consists of 9 questions regarding compensation (X1), 5 questions regarding job safety (X2), 4 questions regarding career path (X3), 3 questions regarding communication (X4), 6 questions regarding relationships with superiors (X5), 5 questions regarding work-life balance (X6) - all six are independent variables, 4 questions regarding job satisfaction ( $\mathrm{Z}$, intermediate variables), and 4 questions about resignation $(\mathrm{Y}$, dependent variable).

In the instrument test, the validity test shows that the items in the questionnaire are valid, while the reliability test shows Cronbach's Alpha value of 0.640 which means the items in the questionnaire are reliable.

In the classic assumption test, the following results are obtained. From the results of the Normality test using the Kolmogorov-Smirnov One-Sample Test, a significance value of 0.058 or greater than 0.05 is obtained, so it can be concluded that the residual value is normally distributed. From the Multicollinearity test, the Tolerance value for each variable is greater than 0.10 , it can be concluded that Multicollinearity does not occur and based on the VIF value all variables are smaller than 10.00 so it can be concluded that Multicollinearity does not occur. In the Heteroscedasticity test, the data points spread above and below around the number 0 . The spread of data points does not form a wavy pattern widened then narrowed and widened again and not patterned so that it can be concluded that heteroskedastic does not occur.

Regression analysis was carried out twice. The first regression sees the effect of compensation, job safety, career path, communication, relationships

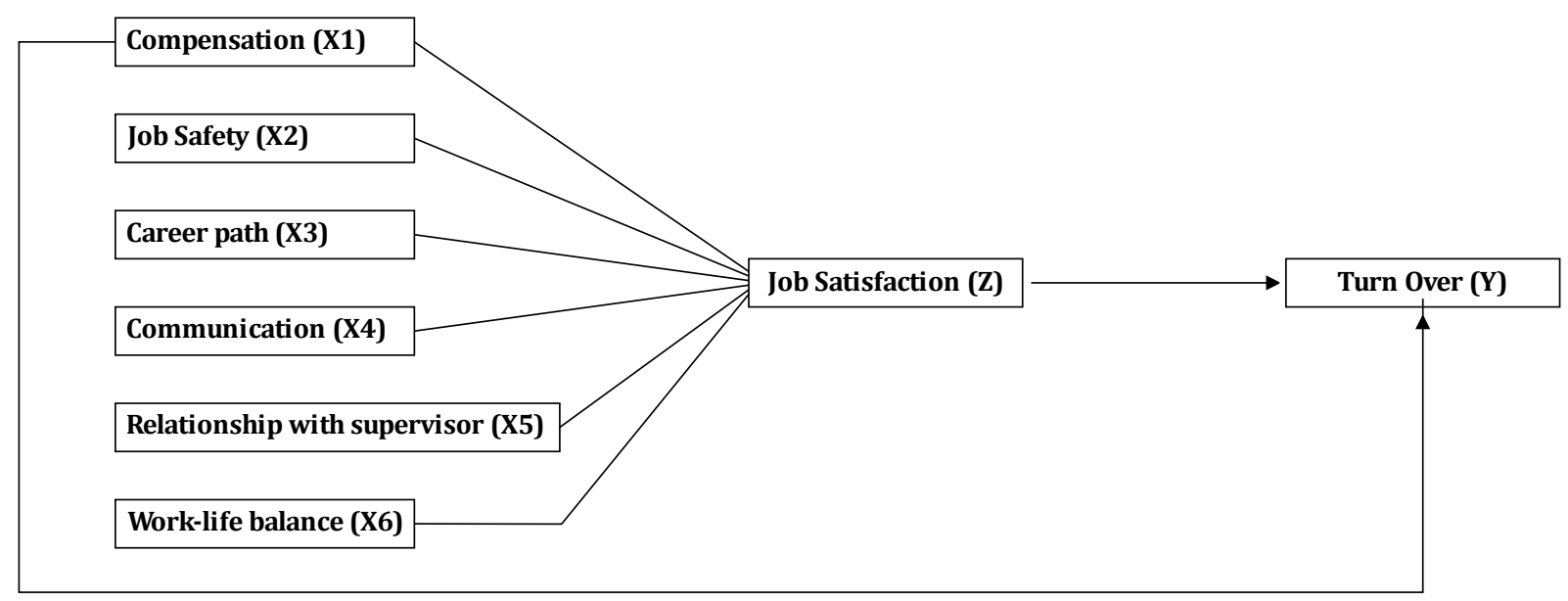

Figure 1. conceptual framework of first regression 
with superiors, and work-life balance on job satisfaction.

Further significance testing is continued by individual testing through the statistical parameter $t$. The test results show a significant effect by taking into account the acquisition of sig. There are three variables that have sig values. smaller than 0.05 namely X1 $=0.011, \mathrm{X} 5=000$, and $\mathrm{X} 6=0.045$, and the three variables have tcount $(\mathrm{X} 1$ $=2.627, \mathrm{X} 5=4.349$ and $\mathrm{X} 6=2.043$ ) greater than ttable (1.99495). This explains that partially compensation (X1), relationship with superiors (X5), and work-life balance (X6) are variables that affect job satisfaction (Z).

Testing the significance of $F$ shows that Fcount $(19,371)$ is greater than Ftable (2.24) and sig. $(0.00)$ is smaller than 0.05 , it can be said that the compensation variable (X1), job safety (X2), career path (X3), communication (X4), relationship with superiors (X5), and work-life balance (X6) simultaneously influence on job satisfaction (Z).

Furthermore, the empirical causal influence between compensation variables (X1), job safety (X2), career path (X3), communication (X4), relationship with superiors (X5), and Work-Life Balance (X6) can be described through subequations structural 1 (one).

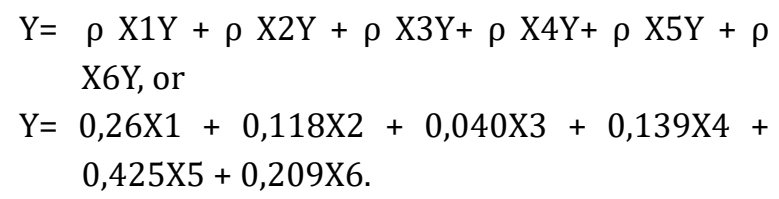

The value of $R$ Square (R2) contained in the Summary Model table is 0.631. It shows that the contribution of compensation (X1), job safety (X2), career path (X3), communication (X4), relationship with superiors (X5), and work-life balance (X6) to job satisfaction (Z) is equal to $63.1 \%$ while the remaining $36.9 \%$ is contributed by other variables not included in the study. Meanwhile, the value of e1 can be found with the formula e1 $=\sqrt{ }(1-0.631)=0.607$. Thus, obtained the path diagram of the structural model I as follows:

The second regression is carried out to see two things, namely the effect of compensation, job safety, career path, communication, relations with superiors, work-life balance, and job satisfaction on resignation (1) and the effect of compensation, job safety, career path, communication, relationship with superiors, and work-life balance through job satisfaction with resignation (2).

Based on the Model II Regression output in the Coefficients table section, there are only two variables that have a sig value. smaller than 0.05 (i.e. compensation $(\mathrm{X} 1)=0.023$ and work-life balance $(\mathrm{X} 6)=0.033$ ) with a tcount greater than ttable 1.99547 (i.e. X1 = $2.333 \&$ X6 = 2.177). These results state that the compensation variable (X1) and work-life balance (X6) have a partially significant effect on resignation (Y).

Based on the statistical output F, Fcount (3.187) is greater than Ftable (2.15) and the value of sig. $(0.00)$ is smaller than 0.05 , it can be concluded

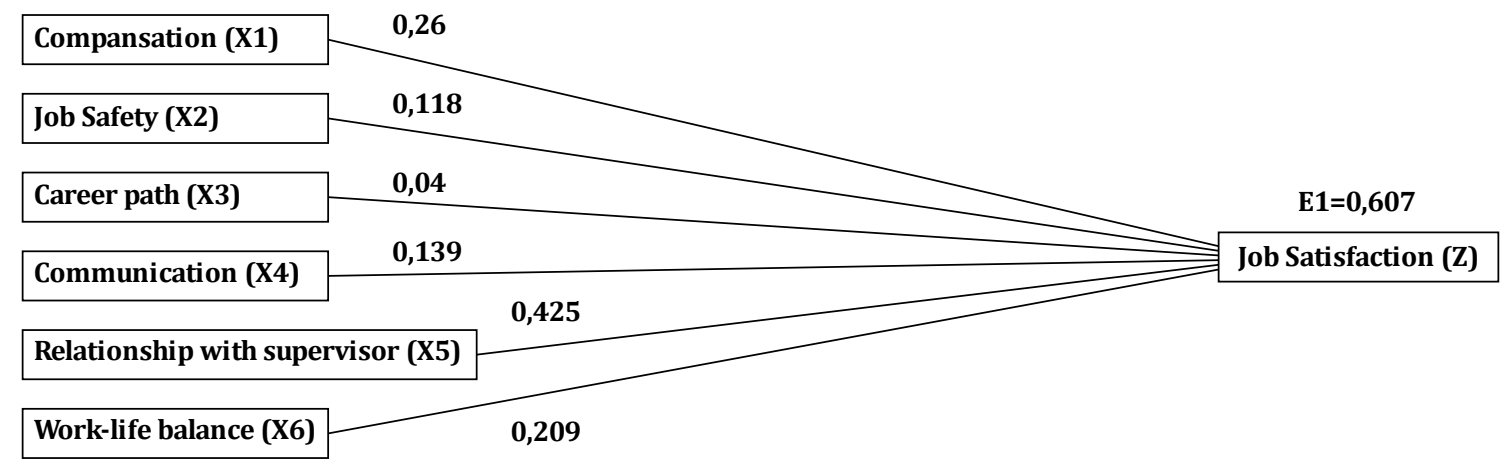

Figure 2. conceptual framework of second regression, carried out to see the effect of compensation, job safety, career path, communication, relations with superiors, work-life balance, on job satisfaction 
that compensation (X1), job safety (X2), career path (X3), communication (X4), relationship with superiors (X5), work-life balance (X6), and job satisfaction (Z) simultaneously influence resignation $(\mathrm{Y})$.

The value of $\mathrm{R} 2$ or $\mathrm{R}$ Square contained in the Model Summary table of 0.250 shows that the contribution of compensation (X1), job safety (X2), career path (X3), communication (X4), relationship with superiors (X5), work-life balance (X6), and job satisfaction $(\mathrm{Z})$ for resignation $(\mathrm{Y})$ is $25 \%$. The remaining $75 \%$ is contributed by other variables not examined. While for the value of e2 $=\sqrt{ }(1-\mathrm{R} 2)=\sqrt{ }(1-0.250)=0.866$. Thus obtained the structure model II path diagram as follows:

\section{RESULT AND DISCUSSION}

This section will answer the research hypothesis: whether there is an effect of compensation, job safety, career paths, communication, relationships with superiors, and work-life balance on job satisfaction (1), whether there is an effect of compensation, job safety, career paths, communication, relationships with superiors, work-life balance, and job satisfaction on resignation (2), and whether there is an effect of compensation, job safety, career path, communication, relationship with superiors, and work-life balance through job satisfaction on resignation (3).

\section{Hypothesis 1}

Based on the results of the first regression analysis, it was found that the six variables simultaneously affected job satisfaction. These six factors contribute considerably and have a strong degree of correlation. This means that to increase employee job satisfaction, MHDC needs to consider fulfilling the six factors, namely compensation, job safety, career path, communication, relationships with superiors, and work-life balance.

The results also showed that compensation, relationships with superiors, and work-life balance

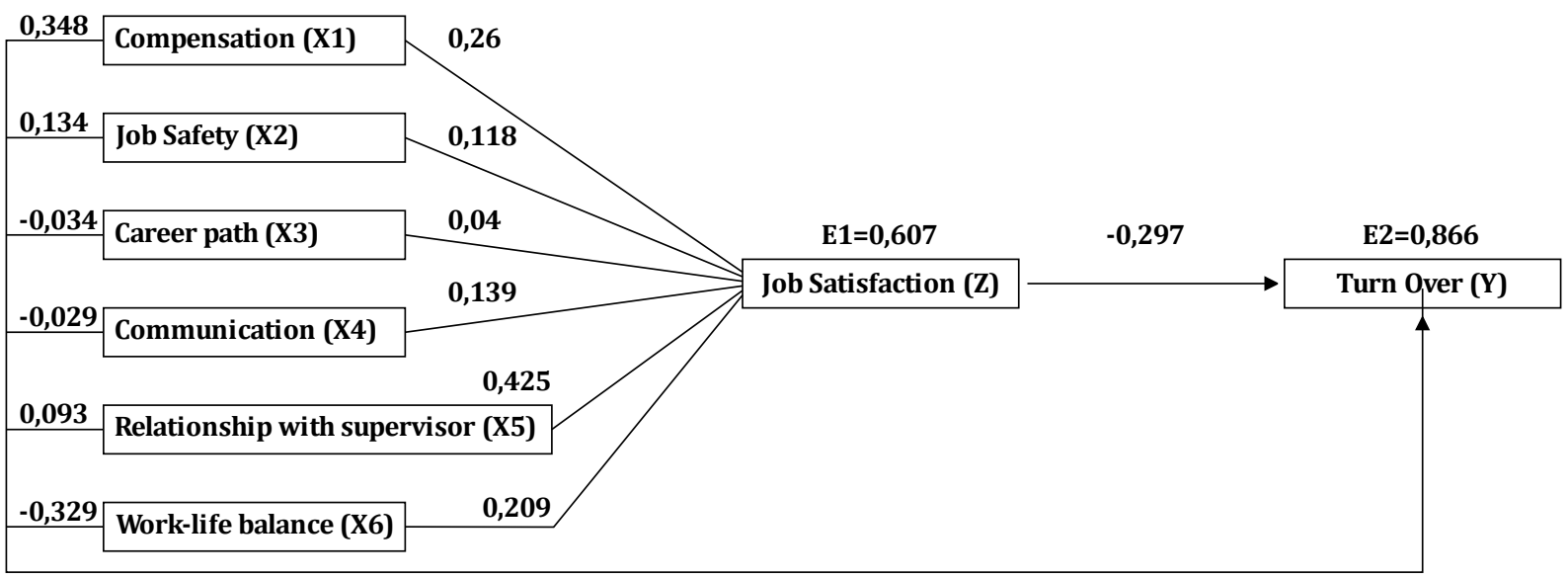

Figure 3. conceptual framework of second regression, carried out to see the effect of compensation, job safety, career path, communication, relations with superiors, work-life balance, on resignation through job satisfaction

Table 1. Hypothesis 3

\begin{tabular}{ccccccc}
\hline Variable & Direct Influence to Y & Variable $\beta$ value & $\beta Z$ value of Y & Influence through Z & Total Influence & Conclusion \\
\hline X1 & 0,348 & 0,260 & $-0,297$ & $-0,077$ & 0,271 & Direct influence \\
\hline X2 & 0,134 & 0,118 & $-0,297$ & $-0,035$ & 0,099 & Direct influence \\
\hline X3 & $-0,034$ & 0,040 & $-0,297$ & $-0,012$ & $-0,046$ & Direct influence \\
\hline X4 & $-0,029$ & 0,139 & $-0,297$ & $-0,041$ & $-0,070$ & influence through Z \\
\hline X5 & 0,093 & 0,425 & $-0,297$ & $-0,126$ & $-0,033$ & Direct influence \\
\hline X6 & $-0,329$ & 0,209 & $-0,297$ & $-0,062$ & $-0,391$ & Direct influence \\
\hline
\end{tabular}


partially affect job satisfaction. While job safety, career paths, and communication, individually, have no influence on job satisfaction. This means that separately, management can increase job satisfaction through the provision of compensation (or can be in the form of bonuses) that attract, improve or improve the quality of relationships between superiors and subordinates, as well as provide greater opportunities for employees to meet the balance between needs in life personal with life at work.

This result is consistent with the theory that compensation is an important reason in every job. If the employee feels that the compensation received is not in accordance with work that is not done, or is not in accordance with the ability of the company (in the perception of employees), then it can affect job satisfaction.

This is also supported by the level of education, where $62.2 \%$ of respondents have a high school / equivalent level and diploma, so they work by expecting adequate compensation to be independent in meeting their needs. Other supporting demographic data is the percentage of respondents married (49.1\%)-who are likely to have more needs than single employees, as well as job positions $(37.7 \%$ are staff and $37.7 \%$ are nurses) which emphasize work compensation to meet their needs.

Relationships with superiors are important because employees at every level need support from their superiors, especially when facing difficulties or problems at work. Even not infrequently when there are personal problems, an employee still needs support from superiors to be able to work well. A good relationship also shows that there is a liquid interaction despite the status of a superior-subordinate. Thus, subordinates do not become rigid towards superiors, and superiors do not feel any distance from subordinates.

This is supported by demographic data that is the position of work as nurses (37.7\%) and staff (37.7\%), which means that they have to work under the supervision of others. Thus, having a good relationship with superiors can be one of the important things that affects job satisfaction of MHDC employees.

Today, work-life balance has become an increasingly important consideration. Despite having a large income, if it then creates an imbalance with personal life, employees can become depressed and feel dissatisfied with their work. This is supported by demographic data in the form of marital status-where 51\% of respondents are family employees (married and never married) and gender-84.9\% of respondents are women.

In a society that is still dominated by the role of patriarchy, women-especially after marriageare expected to divide their time between work and household life. This expectation is not borne by men so that not many married men share roles with their partners. This is what then raises the need for work-life balance.

\section{Hypothesis 2}

Based on the results of the first regression analysis, it was found that the seven variables simultaneously affected the resignation. But the contribution of the seven factors is not large enough and has a moderate degree of correlation. This shows that there are many other factors, outside of the seven factors that have been studied, which influence the decision of MHDC employees to resign.

However, if seen partially, the factors that influence employee resignation are compensation and work-life balance. This means to avoid the tendency of employees to resign from MHDC, management may consider improving compensation and the balance between personal and work life.

Similar to the explanation in hypothesis 1 , if the employee feels that the compensation received is not appropriate, not only feels dissatisfied, the employee can also decide to resign from his current job. Although in general employees will 
resign if they already have another job instead, it is also possible for employees to resign because the incompatibility of compensation received is considered as a lack of appreciation from the company for their work. Thus, employees can also resign without first looking for another job instead.

Likewise, the work-life balance factor. Despite having a good career, more than enough income, but if it creates an imbalance with personal life, employees can feel dissatisfied with their work, and even want to resign.

However, it should be considered that the correlation in research to explain the second hypothesis is not very strong, and the contribution of the seven factors studied is only $25 \%$. This means that there are still many other factors that can be examined for their effect on an employee's decision to resign.

\section{Hypothesis 3}

Because this hypothesis wants to see the effect of the six variables (compensation, job safety, career path, communication, relationship with superiors, and work-life balance) through job satisfaction on resignation, what will be discussed in this section are only variables that have an influence on resignation yourself through job satisfaction.

The results showed that of the six variables, the only variable affecting employee resignation through job satisfaction was communication. This can be explained as follows.

Communication is a process of exchange and understanding of meaning (Robbins \& Judge, 2013). Communication can run well if each communicating party is able to suppress the presence of disturbances in the communication process. With a message delivered and received well and intact, it brings satisfaction to those who communicate, because then they can seek to continue a thing together or find solutions to a problem together.
In terms of work, good communication creates good relationships in the work environment. This makes work easier to solve, fewer misunderstandings occur, and problems can be solved together. Having friends and superiors to whom someone can communicate and establish good relations is a supporting factor for work that cannot be underestimated. This results in job satisfaction and makes employees not willing to resign.

While the two factors that have no partial effect, both on job satisfaction and resignation, directly or indirectly, are job safety and career path. Job safety is related to the security that an employee gets from his job, while career path is related to the process of improving personal skills, interests, knowledge, motivation, and other characteristics related to his job.

In the case of job safety does not significantly influence job satisfaction or resignation, it may be caused by several things. Half (50.9\%) of respondents were less than 25 years old. This means that their journey in the world of work is still very long. Even if it does not fit into the current job, opportunities are still very open to find other work.

For this generation, the drive to work for the same company for many years does not seem dominant. The generation that is often regarded as a "jumping flea" in the world of work is actually looking for challenges and experiences that are different from various types of work and workplaces. In the case of MHDC employees, this is also supported by the level of education, where $62.2 \%$ of respondents have a high school / equivalent level and a diploma. With this level of education, they are quite satisfied with getting the initial job. As you age and perhaps also increase your level of education, the tendency to choose a suitable workplace will be even greater.

Besides age, $81.2 \%$ of new respondents work for a maximum of 5 years (56.6\% of new respondents work for a maximum of 1 year). This data shows that most employees may not be too concerned 
about job satisfaction because of their limited work experience. Resignation is not necessarily related to job satisfaction, but because you want to try more interesting things.

Another factor that has no partial effect is the career path. This is due to the fact that career paths are not open at the MHDC clinic because as a health clinic, employees are on the professional track. Doctors, for example. Being a level one or level two specialist is not a career path but a profession. By realizing that no career path can be taken, MHDC employees do not consider it a determinant of job satisfaction or resignation.

\section{CONCLUSION}

It should be recalled that this study did not find out how satisfied MHDC employees were with their current jobs and how much they wanted to resign. This study wants to find out what factors (of the six and seven factors mentioned above) that affect job satisfaction and employee resignation.

The conclusion of this study is that all variables appear to have an effect on job satisfaction and resignation, if they appear simultaneously. However, from its influence partially, it appears that compensation and work-life balance have significant effects on both job satisfaction and resignation.

Compensation which has a direct effect on job satisfaction and resignation, seems to be in accordance with Maslow's hierarchy of needs theory which states that the first needs that must be met are physiological. Appropriate compensation and can meet the needs of life is an important measure in one's work. That is, MHDC employees work to make ends meet.

While work-life balance which also has a direct effect on job satisfaction and resignation, seems to be in accordance with a number of studies which state that conflicts between life in the office and outside the office, especially between work and family responsibilities, are a significant source of stress (Robbins \& Judge, 2013, p. 604). This is also consistent with the percentage of female respondents (84.9\%) and married (49.1\%).

Another factor that also influences resignation is communication. In contrast to compensation and work-life balance which have a direct effect, communication affects resignation through job satisfaction. That is, when employees feel the compensation is not appropriate, or family life is disrupted, he will tend to resign, without the need to question whether he is satisfied with his work or not. But when employees feel disturbed communication with colleagues and superiors, then they will feel reduced job satisfaction. If this is allowed to continue, then the employee will tend to resign.

The results of the study did not indicate that communication significantly affected job satisfaction. However, communication is one element in the relationship with superiors. Thus, it is the relationship with the boss that causes direct problems with job satisfaction.

Based on these results, it is suggested that MHDC management needs to pay attention to compensation and work-life balance. At the end of the questionnaire there is an open question that reads "Is there anything else that you think affects your job satisfaction at this company?" Some respondents gave some interesting additional answers, namely shorter work hours, no night shifts, teamwork, personal development, culture, annual bonuses, and non-financial appreciation. The answers can be related to compensation factors (shorter working hours, no night shifts, annual bonuses, and non-financial appreciation) and work-life balance (shorter working hours, no night shifts, personal development, and non-financial appreciation).

Respondents' answers to this open-ended question are keywords that can be used to further understand the management of MHDC employee job satisfaction. Management might be able to start opening up to find out employees who object to the number of nights, for example. Need to find out the cause, not just conclude that the employee concerned is not working well. It is 
possible that other factors influence his reluctance to sleep late, for example there are families who cannot be left behind, or the distance of the house is too far away.

For future researchers, we humbly suggest extending to other factors affecting job satisfaction. The six factors involved in this study are still inadequate. The R Square value of 0.250 indicates that the contribution of compensation, work safety, career path, communication, relationships with superiors, work-life balance, and job satisfaction for resignation is only $25 \%$. The remaining $75 \%$ is contributed by other variables not examined.

\section{REFERE N C E S}

Almigo, N. (2004). Hubungan antara kepuasan kerja dengan produktivitas kerja karyawan. Jurnal Psyche, $1(1), 50-60$.

Dessler, G. (2017). Human Resource Management (15th edition). Essex: Pearson Education, Inc.

Mathis, R. L., \& Jackson, J. J. (2006). Manajemen Sumber Daya Manusia (10th ed.). Salemba Empat.

Mello, J. A. (2006). Strategic human resource management (2nd ed.). Mason: Thomson Corporation.

Mudor, H. (2011). Conceptual framework on the relationship between human resource management practices, job satisfaction, and turnover. Journal of Economics and Behavioral Studies, 2(2), pp.4149. https://doi.org/10.22610/jebs.v2i2.220

Robbins, S. P. (2006). Perilaku Organisasi (10th ed.). Indeks.

Robbins, S. P., \& Judge, T. A. (2013). Organizational Behavior (15th edition). New Jersey: Pearson Education, Inc.

Schultz, D., \& Schultz, S. E. (2006). Psychology and Work Today (Ninth). Prentice Hall PTR. Setiorini, A. (2016). FAKTOR-FAKTOR YANG MEMENGARUHI KEPUASAN KERJA DAN PENGARUHNYA TERHADAP PENGUNDURAN DIRI KARYAWAN (STUDI KASUS: FEMINAGROUP). Jurnal Manajemen Bisnis Krisnadwipayana, 4(2).

Wang, Y.-D., Yang, C., \& Wang, K.-Y. (2012). Comparing Public and Private Employees' Job Satisfaction and Turnover. Public Personnel Management, 41(3), 557-573. https://doi.org/10.1177/ 009102601204100310 